\title{
PANDANGAN CINTA DALAM NOVEL UBUR-UBUR LEMBUR KARYA RADITYA DIKA
}

\author{
Laila Namira Rizkika ${ }^{1 *}$, Stella Andrea Fan², Gres Grasia Azmin ${ }^{3}$ \\ Universitas Negeri Jakarta \\ Laila.mira171@gmail.com
}

\begin{abstract}
Abstrak
Pandangan cinta dalam Novel Ubur-Ubur Lembur Karya Raditya Dika adalah masalah dalam penelitian. Penelitian ini dilakukan guna mendeskripsikan cara pengarang menggambarkan kehidupan percintaan yang ada dalam novel Ubur-Ubur Lembur karya Raditya Dika. Tujuan penelitian ini adalah untuk mengetahui dan mendeskripsikan cara berpikir pengarang terhadap aspek percintaan dalam novel Ubur-Ubur Lembur karya Raditya Dika. Pendekatan yang digunakan dalam penelitian ini adalah pendekatan sosiologi sastra oleh lan Watt. Desain penelitian ini bersifat deskriptif kualitatif. Pengumpulan data dilakukan dengan teknik baca catat. Hasil penelitian ini memaparkan bagaimana kehidupan pengarang mempengaruhi karyanya. Sisi percintaan yang dilihat adalah bagaimana pengarang yang mulai bertambah usia dan melihat cinta akan berubah seiring berjalannya waktu. Terlihat pula bagaimana pengarang membaluti tema percintaan dengan unsur komedi, yang membuat novel ini sangat menarik untuk diteliti.
\end{abstract}

Kata Kunci: Novel, Sosiologi sastra, Cinta, lan Watt

\section{PENDAHULUAN}

Karya sastra merupakan teks yang memiliki unsur-unsur dan disusun sedemikian rupa hingga menjadi satu kesatuan. Karya sastra adalah hasil seni dengan bahasa sebagai medianya. Luxemburg, dkk (1984:9) menyatakan bahwa sastra adalah teks-teks yang tidak selalu disusun atau dipakai untuk suatu tujuan komunikatif yang praktis dan yang hanya berlangsung untuk sementara waktu saja. Sebuah karya sastra sejatinya merupakan cerminan dari masyarakat. Ketika membaca sebuah karya sastra, kita dapat melihat bagaimana pengarang melihat dunia melalui tulisannya. Meskipun sastra lahir dari proses imajinatif pengarang, sastra tetap dilandasi oleh kehidupan yang ada di sekitarnya. Menurut Aminuddin (2015:27) cara terbaik untuk menemukan makna yang berhubungan dengan aspek sosial budaya adalah dengan memahami faktor sosial budaya pengarang maupun latar belakang sosial budaya yang melatari terwujudnya teks. Cara pandang seorang pengarang dalam membuat sebuah karya, tentu berbeda-beda karena pengalaman yang berbeda pula. Melalui karya sastra, seorang pengarang dapat pula mengungkapkan persoalan yang ia alami atau yang nyata dilihat sehari-hari. Sebuah karya sastra juga dapat menjadi salah satu bahan untuk seseorang mengetahui kondisi masyarakat saat ini. Menurut Wellek dan Warren (1989:101) dalam teori kesusastraan, pengarang adalah warga masyarakat, ia dapat dipelajari sebagai makhluk sosial.

Hubungan sastra dan sosiologi menjadi sangat besar dalam kajian ini. Menurut Sukanto (dalam Wiyatmi, 2013:6), bahwa sosiologi adalah ilmu yang memusatkan perhatian pada segi-segi kemasyarakatan yang bersifat umum dan berusaha untuk mendapatkan pola-pola umum kehidupan masyarakat. Pengarang juga manusia sosial biasa, maka dari itu hal-hal yang bersifat umum akan menjadi landasan dalam pengarang untuk berkarya. Pengarang yang mengedepankan hubungan sosialnya, maka akan pembaca akan merasakan adanya hubungan dengan karya yang dibaca. Sastra memiliki hubungan dengan masyarakat. Begitu juga ilmu sosiologi. Sosiologi dan sastra sama-sama mengurusi masyarakat. Salah satu cabang sastra adalah sosiologi sastra. Sosiologi sastra membahas aspek-aspek sosial yang terjadi pada masyarakat, termasuk pada kepengarangan sastra. Swingewood (dalam Wiyatmi, 2013:6) menguraikan bahwa sosiologi merupakan studi yang ilmiah dan objektif mengenai manusia dalam masyarakat, studi mengenai lembaga-lembaga dan proses sosial. Maka dari itu bisa dibilang bahwa sosiologi sastra akan berhubungan dengan aspek sosial pada pembuatan karya sastra itu sendiri. Karya sastra tidak sepenuhnya fiktif atau imajinasi belaka, sebuah karya pasti akan 
PANDANGAN CINTA DALAM NOVEL $U B U R-U B U R$ LEMBUR ... $\quad 33$ berhubungan dengan kenyataan yang ada pada sekitar pengarang. Menurut Wiyatmi (2013: 10) sastra juga dapat menjadi sarana untuk menyampaikan nilai-nilai ataupun ideologi tertentu pada masyarakat pembaca.

Sosiologi sastra merupakan suatu pendekatan sastra yang mempertimbangkan segi-segi kemasyarakatan (Damono, 2002:2). Ian Watt mengungkapkan dalam esainya yang berjudul Literature and Society (1964) bahwa adanya hubungan timbal-balik antara sastrawan, sastra, dan masyarakat. Mengutip Damono (2002:4) lan Watt menggunakan tiga konsep pendekatan dalam mengidentifikasi suatu makna dalam teks, di antaranya konteks sosial pengarang (sastrawan), sastra sebagai cerminan masyarakat (karya sastra), dan fungsi sosial sastra (masyarakat). Menurut Wellek dan Warren, sosiologi sastra juga dibagi kembali menjadi sosiologi pengarang. Pengarang adalah makhluk sosial, maka dari itu tempat ia dalam masyarakat sosial akan berpengaruh terhadap karya yang akan ia buat. Sosiologi pengarang berhubungan dengan profesi pengarang dan institusi sastra (Wiyatmi, 2013:28). Masalah yang dikaji antara lain dasar ekonomi produksi sastra, latar belakang sosial, status pengarang, dan ideologi pengarang yang terlihat dari berbagai kegiatan pengarang di luar karya sastra (Wiyatmi, 2013:28).

Karya Raditya Dika yang digunakan dalam penelitian ini adalah Ubur-Ubur Lembur terbitan 2018. Bab yang dikaji adalah bab 1 yang berjudul Dua Orang yang Berubah dan bab 2 yang berjudul Pada Sebuah Kebun Binatang. Novel Ubur-Ubur Lembur karya Raditya Dika ini memiliki jalan cerita yang dilatarbelakangi kehidupannya. Dalam novel tersebut juga dipenuhi dengan aspek pertemanan, percintaan, dan pelajaran hidup yang ada pada kehidupan Raditya Dika. Interpretasi kehidupan pengarang terlihat pada novel Ubur-Ubur Lembur karya Raditya Dika, cara pengarang menggambarkan kehidupan percintaan yang ada disekitarnya. Penelitian sosiologi sastra ini berfokus pada cara pengarang melihat bagaimana percintaan yang terjadi di sekitarnya. Raditya Dika mengemasnya dalam sebuah tulisan lalu menghidupkan "percintaan" dalam perspektif yang banyak orang bisa pahami. Dalam novel Ubur-Ubur Lembur ini Raditya Dika menghubungkan pertemanan dengan percintaan.

Alasan peneliti memilih novel ini karena Raditya Dika adalah salah satu penulis yang karyanya selalu menjadi best seller di pasaran, maka ada banyak orang yang sudah membaca karyanya. Novel Ubur-Ubur Lembur ini juga menjadi karya dalam bidang kepenulisan terbaru dari Raditya Dika. Selain berdasarkan faktor penulis, adapun faktor isi novel. Isi dari novel Ubur-Ubur Lembur ini bisa dibilang cukup berbeda dari karya-karya penulis sebelumnya, maka dari itu peneliti tertarik untuk mengkaji novel ini. Penelitian ini dilaksanakan guna mengemukakan aspek-aspek kepengarangan yang didasari teori lan Watt.

\section{METODE PENELITIAN}

Penelitian ini memiliki sifat deskriptif kualitatif. Sumber data dalam penelitian adalah novel UburUbur Lembur karya Raditya Dika. Dalam penelitian ini berfokus pada pandangan percintaan melalui aspek kepengarangan. Maka dari itu, dalam penelitian ini digunakan teori kepengarangan oleh lan Watt. lan Watt membedakan sosiologi sastra yang mengkaji konteks sosial pengarang, sastra sebagai cermin masyarakat, dan fungsi sosial sastra (Wiyatmi, 2013). Bogdan dan Taylor (dalam Moleong, 2014:44) mendefinisikan metodologi kualitatif sebagai prosedur penelitian yang menghasilkan data deskriptif berupa kata-kata tertulis atau lisan orang-orang dan perilaku yang dapat diamati.

Metode analisis data yang digunakan adalah metode deskriptif analisis. Penelitian deskriptif bertujuan untuk menjelaskan suatu kondisi sosial tertentu (Morissan, 2019:28). Menurut Sugiyono (2017:21) metode analisis deskriptif adalah statistik yang digunakan untuk menganalisis data dengan cara mendeskripsikan atau menggambarkan data yang telah terkumpul sebagaimana adanya tanpa bermaksud membuat kesimpulan yang berlaku untuk umum atau generalisasi. Teknik pengumpulan data yang digunakan dalam penelitian ini adalah teknik baca catat. Data yang diperoleh melalui proses membaca novel Ubur-Ubur Lembur karya Raditya Dika. Adapun data yang digunakan dalam penelitian ini adalah kutipan dari dua bab awal novel Ubur-Ubur Lembur yang berjudul Dua Orang yang Berubah dan Pada Sebuah Kebun Binatang. 


\section{HASIL DAN PEMBAHASAN}

\section{Hasil}

Banyak faktor yang mempengaruhi seorang pengarang dalam membuat karyanya. Sebuah karya akan berkaitan dengan lingkup sosial yang telah dijalaninya. Raditya Dika menulis Ubur-Ubur Lembur berdasarkan apa ia alami, rasakan, dan lihat. Hasil penelitian ini berupa deskripsi data yang diperoleh dengan membaca berulang kali dua bab yang berjudul Dua Orang Yang Berubah dan Pada Sebuah Kebun Binatang. Data dalam penelitian ini bersumber pada novel Ubur-Ubur Lembur karya Raditya Dika. Raditya Dika menuliskan novel ini dari sudut pandangnya. Konteks sosial, kehidupan sosial, dan ideologi pengarang memberi berpengaruh besar pada cara pandang pengarang dalam kehidupan percintaan dalam novel Ubur-Ubur Lembur karya Raditya Dika.

\section{Pembahasan}

Karya sastra merupakan gambaran dari kondisi sosial budaya dari penulis atau pengarang itu sendiri. Bisa dikatakan bahwa karya sastra terlahir dari pengaruh kehidupan sehari-hari pengarang. Adapun faktor-faktor yang mempengaruhi karya sastra untuk terlahir seperti status sosial pengarang, latar belakang pengarang, dan cara pengarang mencari nafkah. Mencari faktor-faktor pengaruh kepengarangan tidak hanya melalui karya pengarang, tetapi bisa juga dilihat dari biografi pengarang, wawancara, maupun sosial media pengarang. Penulis atau pengarang adalah makhluk sosial, maka dari itu pengarang tetap menjadi bagian dari masyarakat umum.

\section{Konteks Sosial Pengarang}

lan Watt (dalam Wiyatmi, 2013) konteks sosial pengarang antara lain mengkaji posisi sosial pengarang dalam masyarakat dan kaitannya dengan pembaca. Pengarang memiliki hubungan yang erat dengan karyanya. Raditya Dika yang memiliki nama lahir Dika Angkasaputra Moerwani Nasution lahir pada 28 Desember 1984 di Jakarta. Beliau adalah anak sulung dari lima bersaudara. Raditya Dika merupakan seorang komika, penulis, sutradara, produser film, YouTuber, juga memiliki sebuah podcast. Kiranya banyak masyarakat pertama kali mengenal Raditya Dika melalui serial Malam Minggu Miko dan juga melalui video stand-up comedy miliknya. Meski begitu, masih banyak yang belum tahu bahwa ternyata Raditya Dika memulai kariernya sebagai penulis. Raditya Dika selalu membaluri unsur komedi pada setiap karya-karyanya. Dalam wawancaranya pada YouTube Helmy Yahya Bicara, ia mengungkapkan bahwa ia sudah suka menulis buku komedi sejak kelas 4 SD. Buku itu lalu diberikan kepada teman-temannya untuk dibaca. la juga mengatakan bahwa ia senang jika ada temannya yang tertawa ketika membaca cerita miliknya. Walaupun begitu, ada banyak sekali pelajaran hidup yang dapat diambil dari karyanya. Dalam wawancaranya dengan Colours (01/03/2020), Raditya Dika mengatakan bahwa karya-karyanya lahir melalui proses yang sama. "Semua berawal dari hal yang mengganggu, sesuatu yang saya rasakan. Orang merasakan hal yang saya rasakan, karena setiap orang memiliki masalah."

Buku yang pertama kali ia terbitkan adalah Kambing Jantan pada tahun 2005. Lalu ada pula buku yang terbilang paling banyak dibicarakan yaitu Marmut Merah Jambu yang terbit pada tahun 2010. Buku terakhir yang ia terbitkan adalah Ubur-Ubur Lembur pada tahun 2018. Adapun alasan Raditya Dika menggunakan nama hewan sebagai judul dalam karya-karyanya. Dalam wawancaranya dengan Helmy Yahya, ia mengatakan bahwa ketika ia pergi ke toko buku, judul-judul buku yang ia lihat begitu bagus. Raditya Dika berkata ia pernah diajarkan bahwa "jika tidak bisa menjadi yang terbaik, jadilah yang paling beda". Karena itu ia membuat judul buku-bukunya dengan nama hewan agar berbeda dari yang lain. "Kalau aku beda, aku sendirian." Ujarnya.

Novel Ubur-Ubur Lembur ini adalah karya Raditya Dika pertama setelah vakum dalam dunia kepenulisan selama dua tahun. Novel ini menceritakan kehidupan Raditya Dika yang dibumbui dengan cara pembawaan yang humoris. Isi dari novel ini bercerita mulai dari masalah pertemanan, percintaan, dan hingga perjalanan menjadi orang dewasa. Novel ini memiliki konsep cerita-cerita pendek dalam kehidupan sehari-hari Raditya Dika. Prakata dalam novel Ubur-Ubur Lembur, Raditya Dika mengatakan "Namun, dengan waktu yang semakin lama semakin terbatas, menulis menjadi sebuah kemewahan." Pada kutipan tersebut bisa disimpulkan bahwa Raditya Dika sudah memiliki kesibukan lain selain 
PANDANGAN CINTA DALAM NOVEL $U B U R-U B U R$ LEMBUR ... $\quad 35$ menjadi penulis. Beliau juga sibuk di ranah dunia hiburan lain. Dalam rentang dua tahun telah vakum dari dunia kepenulisan Raditya Dika sibuk dalam membuat dan menyutradarai 2 buah film dengan judul Hangout dan The Guys.

Konteks sosial pengarang yang ada pada bab Dua Orang yang Berubah dapat dilihat dari beberapa kutipan berikut:

(1) "Adri dan Sally adalah tipe orang yang kalau pacaran pasti diumbar di sosial media”.

(2) "Celakanya, pasangan yang sering mengumbar kemesraan di sosial media begitu berantem juga suka diumbar".

(3) "Seiring dengan gue melangkah ke arah mobil, sampai sini gue baru sadar, yang terjadi justru kedua orang ini telah tumbuh berbeda".

Raditya Dika menulis Dua Orang yang Berubah berdasarkan kedua orang temannya yaitu Adri dan Sally. Sebelum masuk ke kisah Adri dan Sally, ia juga memaparkan bagaimana laki-laki dan perempuan memiliki cara yang berbeda ketika menghibur temannya yang sedang patah hati. Di sini, Raditya Dika memiliki peran sebagai "teman" itu. Beberapa kutipan tersebut menjelaskan bagaimana Raditya Dika memandang kedua orang temannya itu sebagai dua orang yang berubah akibat masalah dengan pribadi masing-masing yakni ketidakpercayaan diri.

Adapula pada bab "Pada Sebuah Kebun Bintang" yakni sebagai berikut:

(4) 'Nay, cinta itu kayak permen karet.' Gue menirukan gaya seseorang yang sedang mengunyah permen karet. 'Semakin lo nikmatin, rasanya akan semakin hambar.."

(5) "Cinta itu sebenar-benarnya menyakitkan, mengecewakan, dan pahit. Sadar, Nay".

(6) "Gue bukan orang yang bisa dengan mudah mengumbar kisah-kisah patah hati gue".

(7) "Di dunia ini nggak mungkin ada dua orang, cowok-cewek bisa berteman dekat kalau salah satu dari mereka nggak ada yang naksir. Di antara sahabatan kayak gini, pasti ada naksir. Ya dalam kasus ini, gue".

(8) "Es krim di tangan gue mulai mencair. Gue menjilat kembali lelehannya yang jatuh ke jari. Untuk sesuatu yang begitu manis, kenapa rasanya begitu hambar?”

Raditya Dika memposisikan dirinya dalam novel Pada Sebuah Kebun Binatang sebagai seorang yang sedang menemani temannya yang baru putus dari kekasihnya, Naya, pergi ke kebun binatang untuk menghibur diri. Seperti pada kutipan (4) dan (5) Raditya Dika kerap mengungkapkan bagaimana hambar dan pahitnya cinta. Kutipan (6) menjelaskan bahwa Raditya Dika bukanlah orang yang mudah mengumbar kisah patah hatinya. Lalu pada kutipan (7) Raditya Dika memaparkan pandangannya tentang tidak bisanya terjadi pertemanan antara laki-laki dan perempuan. Hal ini mengimplikasi bahwa pada cerita Pada Sebuah Kebun Binatang ini, Raditya Dika pernah memiliki perasaan yang lebih terhadap temannya sendiri yakni Naya. Akhirnya pada kutipan (8) ia kembali menyinggung hambarnya cinta dengan perumpamaan sepotong es krim.

\section{Sastra sebagai Cermin Masyarakat}

lan Watt mengungkapkan bahwa kajian sosiologi sastra ini mengkaji sejauh mana sastra bisa dianggap sebagai cerminan keadaan masyarakat (Wiyatmi, 2013). Seperti yang sudah dijelaskan sebelumnya, sastra memang merupakan cerminan masyarakat.

Pada bab 1 dengan judul Dua Orang yang Berubah, Raditya Dika menggambarkan bahwa pemikiran perempuan dan laki-laki akan berbeda jika mereka dihadapkan dengan cara mengatasi teman yang baru patah hati. Dalam hal ini, walaupun tidak semua masyarakat melakukan ini, tetapi ada sebagian yang memang melakukan apa yang telah dituliskan pada novel Ubur-Ubur Lembur ini. Bisa 
terlihat pada kutipan berikut:

(9) "Cowok dan cewek, masing-masing memiliki cara yang berbeda dalam menghadapi teman yang baru putus cinta".

Dalam kutipan tersebut, Raditya Dika menjelaskan bahwa tindakan perempuan dan laki-laki akan berbeda jika dihadapkan dengan teman yang baru putus cinta. Hal tersebut bisa dilihat pada masyarakat umum, hal tersebut juga bisa terjadi karena faktor lingkungan pada masing-masing gender. Raditya Dika sebagai laki-laki memberi pendapat yang mewakilkan cara pandang laki-laki di masyarakat umum.

(10) "Mereka lalu berkumpul melihat Instagram si cowok, mencari foto si cowok dengan cewek barunya".

(11) "Cara teman-teman cewek menghibur juga bermacam-macam. Mereka biasanya akan pergi ke karaoke bareng-bareng. Si cewek yang baru putus akan milih lagu, lalu menyanyi sekaligus curhat".

Pada kutipan di atas, Raditya Dika menggambarkan bagaimana perempuan di masyarakat umum biasanya melakukan tindakan "pembelaan" terhadap teman perempuannya yang baru putus cinta. Hal tersebut tidak 'selalu' terjadi di masyarakat umum, tetapi bisa dikatakan sebagian besar perempuan akan melakukannya untuk membantu temannya.

(12) "Cowok itu beda. Kami nggak tahu bagaimana merespon dengan tepat kalau ada teman cowok yang lagi patah hati. Paling-paling kalau ada teman cowok datang lalu curhat, 'Gila! Kemarin cewek gua selingkuh, dia jadian sama temannya sendiri.' Cowok yang dicurhatin nggak tahu harus merespon apa. Paling Cuma bilang 'Sabar, ya, Bro.' Kalau mau menghibur, kalimat berikutnya paling, 'Eh, Real Madrid menang, loh, kemarin.' Udah. Gitu aja".

Dalam kutipan tersebut, Raditya Dika memberikan pandangan pada laki-laki dalam menghibur teman yang patah hati. Berbeda dengan kutipan sebelumnya, di mana perempuan lebih aktif dan lebih memahami dalam mendengarkan cerita teman yang patah hati. Dalam kutipan ini, laki-laki terlihat lebih pasif dalam mendengarkan cerita teman yang patah hati.

\section{Fungsi Sosial Sastra}

Pada fungsi sosial sastra, yang dikaji adalah sejauh mana nilai-nilai sastra berkaitan dengan nilai-nilai sosial. Mengutip Damono (1979) Ian Watt (dalam Wiyatmi, 2013) membagi fungsi sosial sastra dalam tiga pandangan. Pertama adalah pandangan kaum romantik yang mana sastra dianggap sederajat dengan karya pendeta atau nabi sehingga sastra harus berfungsi sebagai pembaharu dan perombak. Kedua adalah pandangan seni untuk seni yang mana sastra dilihat sebagai penghibur saja. Terakhir ada pandangan bersifat kompromis yang mana sastra di satu sisi harus mengajarkan sesuatu dengan cara menghibur.

Frasa Ubur-Ubur Lembur yang digunakan sebagai judul dari novel ini didapatkan Raditya Dika ketika ia melihat orang-orang kantoran yang bekerja tak sesuai minat, hanya mengikuti arus, dan lembur sampai malam tetapi tidak bahagia seperti seekor Ubur-Ubur Lembur. Dalam prakata novel juga penulis mengatakan, "Gue baru sadar, dengan membicarakan hal yang penting, gue bisa kembali menulis dengan lancar karena gue merasa apa yang gue tulis ini harus dibaca oleh orang banyak." Pada kutipan tersebut novel Ubur-Ubur Lembur ini lebih berarah pada proses pendewasaan pada sekitar kehidupan penulis.

Seperti yang sudah disebutkan sebelumnya, Raditya Dika kerap mengemas karyanya dengan unsur-unsur komedi yang menghibur. Dengan kata lain, karya-karyanya tidak pernah lepas dari unsur komedi. Gaya bahasa yang santai turut mendukung aspek komedi tersebut. Raditya Dika membuka novel dengan kisah dua sejoli yang berubah. la juga menceritakan bagaimana laki-laki dan perempuan memiliki cara yang berbeda dalam menghibur teman yang patah hati. Semua hal itu dikemas sedemikian rupa menjadi sesuatu yang menghibur. 
PANDANGAN CINTA DALAM NOVEL UBUR-UBUR LEMBUR .... 37

(13) “Kalau mau menghibur, kalimat berikutnya paling, 'Eh, Real Madrid menang, loh, kemarin.' Udah. Gitu aja”.

(14) "Cowok nggak bisa ngasih kutipan-kutipan bijak semacam, 'Nangis aja, biarin aja. Nanti cinta terbaikmu akan datang.' Atau 'Karma akan selalu datang ke orang-orang seperti itu”.

(15) "Ya, cinta kadang bisa membuat dua orang normal menjadi alay".

(16) "Mobil meninggalkan rumah Sally dan "anjing pemakan manusia" milikinya".

(17) “Asalkan Sally bisa kembali ke pelukan gue, Dit. Gue akan ngelakuin apa pun. Disuruh nyium lo pun gue mau, 'kata Adri, mantap".

(18) "Di depan kandang gorila, Naya kembali curhat".

(19) "Biasanya orang, tuh, masuk terus bilang "Yaaaay, mau lihat gajah", atau "Yaaaay, mau lihat burung", "Yaaay, mau lihat burungnya mas-mas yang lagi nyapu".

Meskipun Raditya Dika menceritakan perjalanan cinta teman-temannya dibalut dengan unsur komedi yang kuat, ia juga memberi pandangan yang kiranya realistis dan solusi atas masalah-masalah yang terjadi. Hal ini menjadikan pembaca dapat pula melihat cara pandang Raditya Dika dalam menyelesaikan permasalahan tentang cinta.

(20) "Gue ngerasa lo dan Sally akan bisa jauh lebih bahagia kalau kalian berdua benar-benar sendir".

(21) "Cowok dan cewek memang memiliki cara yang berbeda. Nggak hanya ketika menghadapi kawan yang tengah patah hati, tetapi juga ketika mereka sendiri berurusan dengan cinta; sedang jatuh cinta ataupun ataupun patah hati. Meskipun cara mereka berbeda, keduanya ternyata punya kesamaan. Sama-sama bisa buta”.

(22) “Cinta itu sebenar-benarnya menyakitkan, mengecewakan, dan pahit. Sadar, Nay”.

(23) "Emang gitu? Lo tahu nggak apa artinya? Itu artinya... lo harus bisa, selain milih orang yang tepat, juga harus memilih keluarga orang yang tepat".

(24) "Jatuh cinta ngebuat lo jadi orang yang berbeda. Lo jadi satu badan penuh hormon, oxytocin, vasopressin. Lo bukan "Naya" lagi, melainkan "makhluk asing yang penuh hormon" ini. Lalu orang akan melihat betapa bedanya lo. Lo jadi nggak dengarin apa perkataan mereka lagi. Dunia lo hanya berputar di dia, dia, dan dia aja”.

Beberapa kutipan dari "Ubur-Ubur Lembur" di atas menjadikan novel ini memiliki daya tarik tersendiri. Dalam novel ini Raditya Dika kerap memaparkan apa yang sering terjadi di dunia nyata. Dengan begitu, pembaca dapat merasa berkenaan dengan apa yang Raditya Dika tulis. Realitas sosial yang ditunjukkan Raditya Dika kiranya menjadi hiburan tersendiri bagi para pembacanya.

\section{PENUTUP}

Berdasarkan hasil penelitian dan pembahasan maka dapat disimpulkan bahwa analisis sosiologi sastra terhadap novel Ubur-Ubur Lembur Karya Raditya Dika menghasilkan kesimpulan bahwa konteks sosial, kehidupan sosial, dan ideologi pengarang memberi berpengaruh besar pada cara pandang pengarang dalam kehidupan percintaan dalam novel Ubur-Ubur Lembur karya Raditya Dika. Konteks sosial pengarangnya, peneliti meninjau dari segi latar belakang kehidupan pengarang yang dianggap mempengaruhi cara pandangan pengarang pada novel Ubur-Ubur Lembur karya Raditya Dika. Di mana novel Ubur-Ubur Lembur karya Raditya Dika menceritakan kehidupan Raditya Dika yang dibumbui dengan cara pembawaan yang humoris. Pada dua bab di novel dengan judul Dua Orang yang Berubah 
dan Pada Sebuah Kebun Binatang berfokus pada cerita percintaan yang terjadi pada Raditya Dika, pada dua bab tersebut pengarang lebih mengarah tentang bagaimana perasaan seseorang dalam hubungan percintaan akan berubah seiring berjalannya waktu.

Guna penelitian selanjutnya, peneliti disarankan untuk meneliti lebih banyak bab sehingga aspek kepengarangan dapat lebih terlihat. Selain itu, jurnal ini juga diharap bisa menjadi sebuah acuan dalam mengkaji bermacam teori sosiologi sastra lainnya.

\section{UCAPAN TERIMAKASIH}

Terima kasih kami ucapkan kepada STKIP Nurul Huda yang sudah memfasilitasi kami dalam pembuatan artikel ini. Tidak lupa kami ucapkan juga kepada Prodi Sastra Indonesia Universitas Negeri Jakarta, yang telah membimbing dalam pembuatan artikel ini.

\section{DAFTAR PUSTAKA}

Arditya, A. 2019. Raditya Dika: Close to The Heart. Diambil kembali dari Garuda Indonesia Colours pada 16 Mei 2021, https://colours-indonesia.com/id/lifestyle-id/interview-id/id-raditya-dika/

Bicara, H. Y. 2020. Ini Lho Rahasia Raditya Dika Sukses Di Kerjaan Apapun Yang Dimasukinya! Salut! I Wawancara. Diambil kembali dari YouTube pada 24 November 2021: https://www. YouTube.com/watch?v=bHmO49AZFU8\&t=637s

Damono, Sapardi Djoko. 2002. Pedoman Penelitian Sosiologi Sastra. Jakarta: Pusat Pembinaan dan Pengembangan Bahasa.

Dika, R. 2018. Ubur-Ubur Lembur. Jakarta: Gagas Media.

Amiruddin. 2015. Pengantar Apresiasi Karya Sastra. Bandung: Penerbit Sinar Baru Algensindo.

Fitrah, M. 2018. Metodologi Penelitian: Penelitian Kualitatif, Tindakan Kelas \& Studi Kasus. Sukabumi: CV Jejak (Jejak Publisher).

J.Moleong, Lexy.2014. Metode Penelitian Kualitatif, Edisi Revisi. PT Remaja Rosdakarya, Bandung.

Luxemburg, J. V. 1984. Pengantar IImu Sastra. (D. Hartoko, Penerj.) Jakarta: PT Gramedia.

Morissan. 2019. Riset Kualitatif. Jakarta: Prenadamedia Group.

Sugiono.2017. Metodologi Penelitian: Penelitian Kualitatif (Tindakan Kelas \& Studi Kasus). Sukabumi: CV Jejak.

Suhariyadi. 2014. PENGANTAR ILMU SASTRA Orientasi Penelitian Sastra. Tuban: CV Pustaka llalang Group.

Warren, R. W. 1989. Teori Kesusastraan. (M. Budianta, Penerj.) Jakarta: PT Gramedia Pustaka Utama.

Wiyatmi. 2013. Sosiologi Sastra. Yogyakarta: Kanwa Publisher. 